\title{
PENGGUNAAN RADIOISOTOP PADA DETEKSI DINI PENYAKIT KANKER
}

\author{
${ }^{1}$ Pingkan Senduk \\ ${ }^{2}$ Vennetia R. Danes, \\ ${ }^{2}$ Jimmy F. Rumampuk
}

\author{
${ }^{1}$ Kandidat Skripsi Fakultas Kedokteran Universitas Sam Ratulangi Manado \\ ${ }^{2}$ Bagian Fisika Fakultas Kedokteran Universitas Sam Ratulangi Manado \\ Email: pingkansendowsenduk@yahoo.com
}

\begin{abstract}
Application of nuclear techniques, both the applications of radiation and radioisotopes, are very useful since the use of atomic energy program for peaceful purposes was launched in 1953. Positron Emission Tomography (PET) is a new method for imaging the physiological functions of human tissues. Radiant energy emitted by a source of radiation can cause changes in terms of physical, chemical, and biological material in its path. Changes that occur can be controlled by choosing the type of radiation (or neutron) and regulate the dose absorbed, according to the effect needed to be achieved. Based on these properties, the radiation can be used directly such as in radiotherapy, and sterilization. In addition, the radiation emitted by a radioisotope, location and distribution can be detected from outside the body proper, and its activity can be measured accurately; therefore, the use of radioisotopes as tracer is very useful in metabolic studies, as well as tracking techniques and management or treatment of various organs, without having to perform surgery, particularly its use for early detection of cancer cells, or better known methods of cancer with PET.
\end{abstract}

Keywords: radioisotopes, cancer, tracer, PET

\begin{abstract}
Abstrak: Aplikasi teknik nuklir, baik aplikasi radiasi maupun radio-isotop, sangat dirasakan manfaatnya sejak program penggunaan tenaga atom untuk maksud damai dilancarkan pada tahun 1953. Positron Emission Tomography (PET) merupakan metode terbaru untuk mencitrakan fungsi fisiologis jaringan tubuh manusia. Energi radiasi yang dipancarkan oleh suatu sumber radiasi dapat menyebabkan perubahan dari segi fisis, kimia dan biologi pada materi yang dilaluinya. Perubahan yang terjadi dapat dikendalikan dengan jalan memilih jenis radiasi (atau neutron) serta mengatur dosis terserap, sesuai dengan efek yang ingin dicapai. Berdasarkan sifat tersebut, radiasi dapat digunakan untuk penyinaran langsung seperti antara lain pada radioterapi, dan sterilisasi. Selain itu, radiasi yang dipancarkan oleh suatu radioisotop, lokasi dan distribusinya dapat dideteksi dari luar tubuh secara tepat, serta aktivitasnya dapat diukur secara akurat; sehingga penggunaan radioisotop sebagai perunut, sangat bermanfaat dalam studi metabolisme, serta teknik pelacakan dan penataan berbagai organ tubuh, tanpa harus melakukan pembedahan, khususnya dalam penggunaannya untuk mendeteksi dini sel kanker atau yang lebih dikenal penyakit kanker dengan metode PET.
\end{abstract}

Kata kunci: radioisotop, penyakit kanker, perunut (tracer), PET

Saat ini kanker merupakan salah satu penyakit yang mematikan. Banyak bentuk kanker yang disebabkan dengan faktor lingkungan maupun gaya hidup yang sebenarnya dapat dihindari, misalnya merokok dan pola makan yang tidak sehat. 
Pada dasarnya tubuh manusia secara alami melakukan penjagaan terhadap kanker dengan berbagai metode seperti kematian sel yang terprogram, molekul pembantu (beberapa polimerase DNA), penuaan (senescence), dan lain-lain. Namun metode koreksi kecatatan atau pencegahan ini seringkali gagal terutama di lingkungan yang memungkinkan terjadi bahkan mendukung terjadinya kecatatan sel tersebut. Contohnya lingkungan tertentu mengandung bahan-bahan yang merusak yang disebut dengan karsinogen atau lingkungan yang membuat sel tidak mampu bertahan seperti hipoksia. ${ }^{1}$

Hal inilah yang menjadi salah satu latar belakang oleh para ilmuan khususnya dalam bidang Kedokteran Nuklir menggali lebih dalam lagi manfaat radioisotop. Selain banyak dimanfaatkan sebagai terapi berbagai penyakit radioisotop dapat juga menjadi alat deteksi dini (tracer/perunut) sel kanker pada tubuh manusia. ${ }^{2}$

Awalnya, yang dikenal untuk mendeteksi kanker ialah dengan metode Computed Tomography Scan (CT Scan) yaitu mendeteksi untuk mengetahui letak kanker dengan menggunakan sinar $\mathrm{X}$. Salah satu metode mutakhir untuk mendeteksi sel kanker sebelum menjadi sel kanker aktif yang berkembang membahayakan tubuh ialah dengan metode Positron Emission Tomography (PET) CT Scan. PET CT scan ini merupakan metode yang menggabungkan metode PET dan CT dengan menggambarkan fungsi fisiologis jaringan tubuh manusia termasuk aktifitas metabolik dan berbagai proses kimiawi baik karena virus, bakteri, kelainan genetik, berbagai obat obatan, faktor lingkungan, dan usia. $^{2}$

Dalam metode PET sebagai pelacak sel kanker, cairan yang mengandung glukosa disuntikkan kedalam tubuh. Hal ini dikarenakan sel kanker menyerap lebih banyak glukosa untuk berkembang atau berploriferasi. Bila banyak glukosa terserap di bagian tubuh tertentu, dengan warna abu-abu yang lebih gelap pada hasil scan, hal itu menunjukkan adanya sel kanker yang aktif. ${ }^{2}$

\section{RADIOISOTOP}

Radioisotop adalah isotop dari zat radioaktif yang mampu memancarkan radiasi, dapat terjadi secara alamiah (radioisotop alam) ataupun disengaja (dibuat oleh manusia), dan bisa dibuat sesuai dengan keperluan. Radioisotop alamiah umumnya lebih mahal dari pada radioisotop buatan; hal ini disebabkan karena berkaitan dengan proses pemurniannya. ${ }^{2,3}$

Penggunaan radioisotop untuk bidang kedokteran mempunyai syarat yang lebih khusus. Hal ini disebabkan karena sasaran pemakaiannya manusia, sehingga memerlukan tingkat kehati hatian dan kecermatan yang lebih dengan pemakaian radioisotop dalam bidang yang lainnya.,

\section{Radioisotop sebagai alat deteksi dini (tracer) dengan metode PET}

PET merupakan salah satu hasil terdepan pengembangan teknologi nuklir di bidang kedokteran. PET adalah metode visualisasi metabolisme tubuh menggunakan radioisotop pemancar positron. Oleh karena itu, citra (image) yang diperoleh ialah citra yang menggambarkan fungsi organ tubuh. Kelainan fungsi atau metabolisme di dalam tubuh dapat diketahui dengan metode pencitraan (imaging) ini. Hal ini berbeda dengan metode visualisasi tubuh yang lain seperti Magnetic Resonance Imaging (MRI) dan CT yang mendeteksi kelainan bentuk organ tubuh. $^{4,5}$

Berbagai kelainan metabolisme di dalam tubuh, termasuk di dalamnya ialah adanya metabolisme sel kanker, dapat diketahui dengan cepat melalui PET. Salah satu bentuk perbedaan sel kanker dengan sel normal di sekelingnya ialah pada metabolisme glukosa. Sel kanker mengonsumsi glukosa dalam jumlah yang lebih besar dari sel di sekelilingnya. Secara umum, kecepatan pertumbuhan sel kanker 
yang mencerminkan tingkat keganasannya sebanding dengan tingkat konsumsi glukosa. Bentuk metabolisme glukosa di dalam tubuh ini dapat dideteksi menggunakan bahan radiofarmaka ${ }^{18} \mathrm{FDG}$ ( ${ }^{18} \mathrm{~F}$-2-fluoro-2-deoxy-D-glucose). ${ }^{4-6}$

\section{Radioisotop dengan metode PET sebagai perunut (tracer) pada penyakit kanker}

Keberadaan radioisotop fluor-18 yang terdapat pada senyawa ${ }^{18}$ FDG dapat dideteksi dengan mudah dari luar tubuh melalui radiasi yang dipancarkannya. Dengan meletakkan detektor radiasi di luar tubuh, image reconstruction terhadap sebaran fluor-18 di dalam tubuh dapat dilakukan dengan mengolah sinyal-sinyal yang ditangkap oleh detektor detektor tersebut. Sebaran fluor-18 di dalam tubuh ini menunjukkan pola metabolisme glukosa di berbagai bagian tubuh. Konsumsi glukosa yang berlebihan di suatu tempat mengindikasikan adanya metabolisme sel kanker di tempat tersebut. Inilah yang dinamakan menemukan kanker dalam bentuk benih. Meskipun secara bentuk fisik belum ditemukan atau belum terdeteksi, keberadaan kanker telah diketahui ketika metabolisme sel kanker telah terjadi. ${ }^{2,3,7}$

Kemampuan radioisotop memburu kanker pada stadium ini belum dapat ditandingi oleh metode lain. Penemuan adanya sel kanker pada stadium sangat dini ini akan memudahkan penanganan selanjutnya yang diperlukan untuk melihat keberadaan metabolisme sel kanker. Kombinasi PET dan CT memberikan informasi yang sangat berharga dalam mendeteksi sedini mungkin adanya sel kanker dalam tubuh manusia., 2,7

\section{Pencegahan pengaruh buruk pada manusia dalam penggunaan radioisotop}

Tindakan proteksi radiasi yang dilakukan tentunya merupakan tindakan proteksi radiasi terhadap paparan radiasi sinar-X. Jadi merupakan tindakan proteksi radiasi eksterna karena sumber radiasi berada di luar tubuh manusia. Sebelum menerangkan apa yang dimaksud dengan tindakan proteksi radiasi eksterna terlebih dahulu perlu dipahami mengenai pengertian, falasah, dan tujuan proteksi radiasi. $^{2,8}$ Proteksi radiasi atau fisika kesehatan dan keselamatan radiasi adalah suatu cabang ilmu pengetahuan yang berkaitan dengan teknik kesehatan yang perlu diberikan kepada seseorang atau kelompok orang terhadap kemungkinan diperolehnya akibat negatif dari radiasi pengion. ${ }^{8}$

\section{SIMPULAN}

Positron Emission Tomography (PET) merupakan salah satu hasil di garis depan pengembangan radioisotop untuk dunia kedokteran. Aplikasi radioisotop dalam deteksi dini sel kanker dengan metode PET memiliki kemampuan untuk memburu, bahkan membunuh sel kanker secara efektif pada tahap yang paling dini ketika kanker masih berupa benih, yaitu saat metabolisme sel kanker mulai terjadi.

\section{SARAN}

Perlu dilakukan penelitian lanjutan untuk pemantauan pengaruh buruk baik pada pekerja penyinaran maupun pasien akibat radiasi.

\section{DAFTAR PUSTAKA}

1. Cameron JR, Skofronick JG, Grant RM. Fisika Tubuh Manusia (Edisi ke-2). Alih Bahasa: Pendit BU. Jakarta: EGC, 2006; p. 213-5.

2. Enghyst HN, Cummings JH. Non-starch polysaccharides (dietary fiber) and resistant starch. In: Furda I, Brine CJ, editors. New developments in dietary fiber. Physiological, physicochemical, and analytical aspects. New York: Plenum Press, 1990; p. 205-25.

3. Pearce E. Anatomi dan Fisiologi untuk Paramedis. Jakarta: Gramedia Pustaka Utama, 2008; p. 325-30.

4. Gabriel JF. Fisika Kedokteran. Jakarta. ECG, 1996; p. 13-15, 231-35.

5. Manfaat radioisotop untuk mendiagnosa berbagai macam penyakit. 2011. 
Available

from: http://www.indonesiapintar.or.id/index. php/Teknologi-Terapan/Diagnosa

Berbagai-Penyakit-dengan-

Radioisotop.html.

6. Phillips SJ, Whisnant JP. Hypertension and stroke. In: Laragh JH, Brenner BM, editors. Hypertension: Pathophysiology, Diagnosis, and Management (2nd ed.). NewYork: Raven Press, 1995; p. 465-78.
7. Hani A, Riwidikdo H. Fisika Kesehatan. Jogjakarta: Mitra Cendikia Press, 2009; p. 117-43.

8. Radiasi pengion dosis rendah dan resikonya (serial online). Available from: http://www.infonuklir.com/readmore/re ad/keamanan_keselamatan/proteksi_rad iasi/1cq4ju1/Radiasi\%20pengion\%20dosis\%renda h\%20dan\%resikonya 